\title{
Siderosis bulbi resulting from an intraocular metalic foreign body: case report
}

\section{Siderose ocular causada por corpo estranho metálico intraocular: relato de caso}

Ricardo Evangelista Marrocos de Aragao ${ }^{1}$. Ieda Maria Alexandre Barreira ${ }^{2}$. Gustavo Jose Arruda Mendes Carneiro $^{3}$. Nayara Queiroz Cardoso Pinto ${ }^{3}$. Talles Peterson Cavalcante Oriá3 ${ }^{3}$ Jhonatan de Paula Araujo Ferreira $^{3}$. Igor Costa Menezes ${ }^{3}$.

1 Doutor em oftalmologia pela Universidade de Regensburg, Ratisbona, Alemanha. 2 Oftalmologista do Centro Integrado de Diabetes e Hipertensão, Fortaleza, Ceará, Brasil. 3 Médico, residente de Oftalmologia do Hospital Universitário Walter Cantídio (HUWC), Fortaleza, Ceará, Brasil.

\section{ABSTRACT}

Siderosis bulbi is a sight-threatening condition characterized by a pigmentary and degenerative change in the eye that follows the intra-ocular retention of a foreign body containing iron. The main cause of ocular siderosis is penetrating trauma mostly by hammering a steel object without or with poor eye protection. Herein, we report a case of siderosis bulbi after penetrating trauma that was lately treated with vitrectomy to remove the foreign body, and despite treatment resulted in ocular globe atrophy.

Keywords: Retina. Vitrectomy. Wounds and injuries. Optic atrophy. Night blindness.

\section{RESUMO}

Siderose ocular é caracterizada por alterações pigmentares e degenerativas oculares causada por retenção de corpo estranho intraocular contendo ferro, que pode levar à perda da visão. A principal causa de siderose ocular é o trauma penetrante, causado principalmente por martelar objetos de metal com pouca ou nenhuma proteção ocular. Relatamos o caso de um paciente com siderose ocular causado por trauma penetrante, que foi tratado tardiamente com vitrectomia para remoção do corpo estranho e apesar do tratamento evoluiu com atrofia do globo ocular.

Palavras-chave: Retina. Vitrectomia. Ferimentos e lesões. Atrofia óptica. Cegueira noturna.

Corresponding Author: Ricardo Evangelista Marrocos de Aragao, Rua Osvaldo Cruz, 2335, Dionísio Torres, Fortaleza, Ceará. CEP: 60125-151. Telefone: +5585 99137-9313. E-mail: ricardomarrocos@yahoo.com

Conflict of interests: The authors have no conflicts of interest to declare.

Received: 26 May 2016; Revised: 25 Jul 2016; Accepted: 09 Aug 2016. 


\section{INTRODUCTION}

Ocular siderosis is the reaction of the eye to a retained iron foreing body. The iron accumulate particulary in the epithelial structures, such as dilatador muscle of the iris, nonpigmentated ciliary epithelium, lens epithelium, retinal pigment epithelium and the retina. The most commom cause of eye siderosis is the perforation of the eye by iron fragments usually by grinding, drilling, or striking metal in the setting of poor eye protection. ${ }^{1}$ High-velocity metal fragments could penetrate the cornea or sclera without a visible entry site due to their small size and to the corneal self-seal wounds. Patients tipically present with persistent ocular irritation and redness with or without change in visual acuity. ${ }^{2}$ If iron foreing body is left in the eye, it can cause the sideroris, which is characterized by a rust-colored corneal stroma, greenish-brown iris discoloration, yellow cataract with brown deposits on the anterior capsule, pigmentary retinal degeneration, optic disc swelling/ hyperemia and optic atrophy. ${ }^{3}$ The removal of the retained foreing body is the mainstay of the treatment.

\section{CASE REPORT}

A 46 year-old man referred low progressive visual acuity for 08 months in the right eye, triggered by penetrating trauma with metallic material in his right eye. He was hammering a steel object without wearing safety glasses.

On examination, he had visual acuity of light perception in the right eye and 20/25 in the left eye. On slit-lamp examination, was observed a yellow cataract with brown deposits on the anterior capsule, presence of brownish pigments in epithelium and corneal stroma, opacity of anterior chamber with siderotic pigments, fixed mydriasis and iris heterochromia (Figure1). Intraocular pressure was 04 and $12 \mathrm{mmHg}$ in the right and left eye respectively. Fundoscopy was impractical in the right eye and was normal in the left eye. A B-Scan ultrasound of the right eye showed silent vitreous and retina applied. The orbits $\mathrm{X}$-Ray showed linear metallic artifact in the projection of the right orbtit cavity (Figure 2).

Figure 1. Observed a yellow cataract with brown deposits on the anterior capsule, presence of brownish pigments in epithelium and corneal stroma, opacity of anterior chamber with siderotic pigments, fixed mydriasis and iris heterochromia.

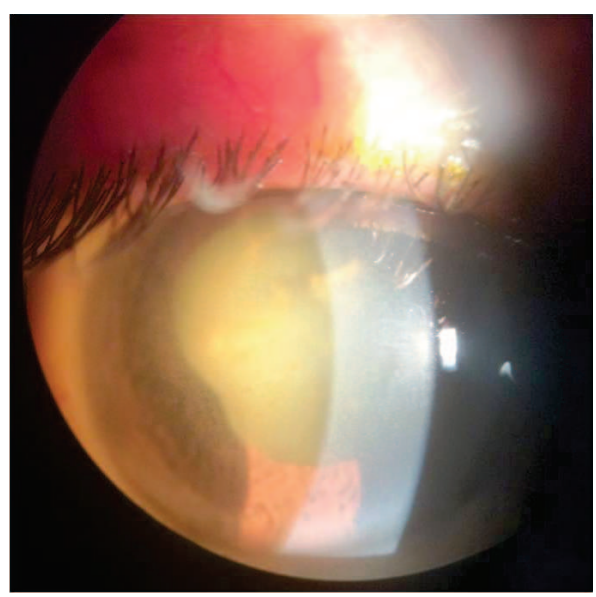

Figure 2. The orbits X-Ray showed linear metallic artifact in the projection of the right orbtit cavity (arrow).

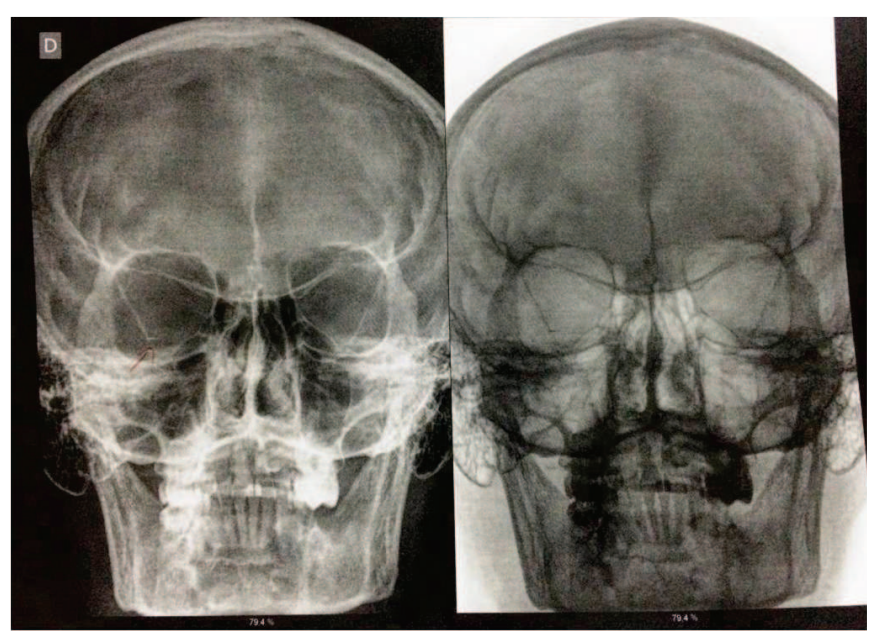

Pars plana vitrectomy and catartact surgery was peformed for removal of metallic material (Figure 3). Three months after the removal of the iron foreign body visual acuity dropped to no light perception in the right eye.

Figure 3. The removed intraocular metalic foreing body.

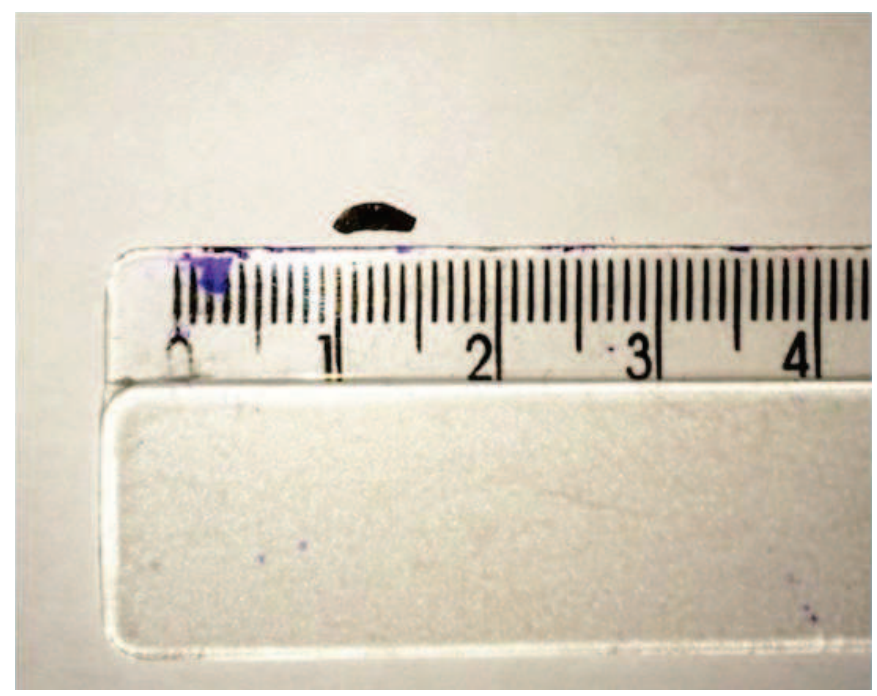

\section{DISCUSSION}

Siderosis bulbi is a sight-threatening complication of a retained iron-containing intraocular foreign body and may occur from 18 days to 08 years after ocular trauma. ${ }^{4}$ Classical findings are characterized by iris heterochromia, pupilary mydriasis, cataract formation, retinal pigmentary degeneration and occasionally secondary glaucoma. ${ }^{5}$ These findings are caused by the dissociation of metallic foreign body resulting in iron deposits in the epithelial structures, such as the dilator muscle of the iris, lens epithelium, nonpigmented ciliary epithelium, retinal pigment epithelium and retina, which cause toxic effects resulting in cells death. ${ }^{6}$ Intraocular metal 
foreign bodies commonly occur in the setting of construction, machining, or auto repair. Hammering steel is the commonest cause of injury. ${ }^{7}$ The history is usually of striking metal in the setting of no or poor eye protection. Patients typically showed ocular irritation and redness, with or without alterations in visual acuity. ${ }^{2}$ The diagnosis is usually made by slit lamp examination, which can detect foreign body in lens, anterior chamber and by a dilated fundus examination, when it is possible. If the foreign body is not clinically evident, orbits computed tomography, ultrasonography B-Scan can be performed. A plain orbital X-ray is the recommended imaging for detection of an intraocular foreign body, but if negative a computed tomography scan is then performed. ${ }^{8}$ Magnetic resonance imaging is very sensitive in detecting foreign bodies, however, is limited because of the threat of a magnetic object's movement during the test, which can cause more damage. ${ }^{3}$ The most common symptoms are nyctalopia, constricted visual field, decreased vision and eletroretinographic changes.

Pars plana vitrectomy is the mainstay treatment of intraocular foreign bodies located posteriorly. Extracapsular cataract extraction using phacoemulsification or nuclear expression

\section{REFERENCES}

1. Talamo JH, Topping TM, Maumenee AE, Green WR. Ultrastructural studies of cornea, iris and lens in a case of siderosis bulbi. Ophthalmology. 1985;92(12):1675-80.

2. Benson WB. The incidence of intraocular foreign bodies and other intraocular findings in patients with corneal metal foreign bodies. Evidence-Based Ophthalmology. 2011;12(2):76-7.

3. Mester V, Kuhn F. Intraocular foreign bodies. Ophthalmol Clin North Am. 2002;15(2):235-42.

4. Sneed SR, Weingeist TA. Management of siderosis bulbi due to a retained ironcontaining intraocular foreign body. Ophthalmology. 1990;97(3):375-9.

5. O'Duffy D, Salmon JF. Siderosis bulbi resulting from an intralenticular foreign body. Am J Ophthalmol. 1999;127(2):218-19. with posterior chamber intraocular lens implantation may be the procedure of choice for visual rehabilitation of eyes with siderotic cataract.

Loss of vision is usually owing to retinal degeneration. The disappearance of symptoms and signs of siderosis following removal of the foreign body has been reported, however, if the iron foreign is left in the eye, or even when it is removed it may cause permanent visual loss. ${ }^{9}$ Moreover, complications following surgery are rather common as postoperative retinal detachment and proliferative vitreoretinopathy. The mass of the intraocular foreign body is a prognostic factor due to its higher kinetic energy, which can cause more damage to the eye tissues. ${ }^{10}$

Suspicion of retained intra-ocular foreign body must be investigated in all patients with suspicion of penetrating trauma. The removal of the intra-ocular foreign body should be strongly recommended to avoid the development of ocular siderosis. Although the foreign body is most often surgically removed, in some instances it may be left within the eye. In these cases, close follow-up is recommended.

6. Gerkowicz K, Prost M, Wawrzyniak M. (1985). Experimental ocular siderosis after extrabulbar administration of iron. $\mathrm{Br} \mathrm{J}$ Ophthalmol. 1985;69(2):149-53.

7. Ballantyne JF. (1954). Siderosis bulbi. Br J Ophthalmol. 1954;38(12):727-33.

8. Lapira M, Karl D, Murgatroyd H. Siderosis bulbi as a consequence of a missed intraocular foreign body. BMJ case reports. 2014;2014:1-3.

9. Zhu L, Shen P, Lu H, Du C, Shen J, Gu Y. Ocular trauma score in siderosis bulbi with retained intraocular foreign body. Medicine (Baltimore). 2015;94(39):e1533.

10. Loporchio D, Mukkamala L, Gorukanti K, Zarbin M, Langer P, Bhagat N. Intraocular foreign bodies: a review. Surv Ophthalmol. 2016;61(5):582-96.

\section{Como citar:}

Aragao RE, Barreira IM, Carneiro GJ, Pinto NQ, Oriá TP, Ferreira JP, et al. Siderosis bulbi resulting from an intraocular metalic foreign body: case report. Rev Med UFC. 2017 jan-abr;57(1):63-65. 